\title{
THE IMPLEMENTATION OF BUDDY VOCABULARY CARDS TECHNIQUE TO IMPROVE READING COMPREHENSION
}

\author{
Agus Wilson \\ Program of Informatics, Faculty of Technique Information and Computer, \\ University of Indraprasta PGRI \\ Jalan Nangka No. 58C Tanjung Barat, Jagakarsa, South Jakarta 12530 \\ wilsonaw2580@gmail.com
}

\begin{abstract}
This research is aimed to propose a model of learning for English teacher to improve reading comprehension of discourse in English and to see whether the Buddy Vocabulary Cards Technique has reached the level of effectiveness to be presented to students. The research was held at SMK AL-MAKMUR in South Jakarta Class 1, the population of 239 students with a sample that was taken randomly about 44 students. Research methods are library studies and field studies with through debriefing and giving some questions. Based on the results, it can be concluded that the Buddy Vocabulary Cards technique can be used to improve students' reading comprehension. The result of study identifies that the average value of the students have achieved good category, with an average value of 6.8.
\end{abstract}

Key words: Buddy Vocabulary Cards Technique, reading comprehension, learning model

\section{ABSTRAK}

Penelitian ini bertujuan untuk mengajukan model pembelajaran bagi para pengajar bahasa Inggris untuk meningkatkan kemampuan pemahaman membaca wacana berbahasa Inggris dan melihat apakah Teknik Buddy Vocabulary Cards sudah mencapai tingkat efektifitas untuk disajikan kepada siswa. Penelitian diadakan di SMK ALMAKMUR Jakarta Selatan kelas I dengan total populasi sebanyak 239 siswa dan diambil sampel secara acak untuk penelitian sebanyak 44 siswa. Metode yang digunakan adalah studi pustaka dan studi lapangan dengan melalui tanya jawab dan memberikan beberapa soal. Berdasarkan hasil penelitian, dapat disimpulkan bahwa Teknik Buddy Vocabulary Cards dapat digunakan untuk meningkatkan kemampuan pemahaman membaca siswa. Data menunjukkan nilai rata-rata yang dimiliki siswa telah mencapai kategori baik, dengan nilai rata-rata 6,8 .

Kata kunci: Teknik Buddy Vocabulary Cards, kemampuan pemahaman membaca, model pembelajaran

\section{INTRODUCTION}

Reading is very important to increase one's knowledge because by reading someone can increase their perceptions and ways of thinking, and can obtain very important and useful information from various reading media. Many science books are written in English, so someone needs to have the ability to speak English to understand these books. If people want to increase their perceptions, they have to read many 
English reading materials. They must be aware that they have to be responsible to develop their insight, not others. This is why an ability to read English reading materials is required.

To understand English discourse, vocabulary mastery is needed to understand the discourse that is being read. Increasingly, someone will obtain vocabulary words in English, increase reading comprehension of English discourse. However, a new problem arises, namely how to increase the whole of vocabularies a person has so that later the ability to understand the discourse that is read will increase.

In addition to the number of vocabularies a person has, a person's background can also determine the ability to understand a discourse. For example, students from secretarial majors will find it difficult to understand the discourse about computers. Hard effort is needed to add extensive knowledge to be able to understand various kinds of discourse.

To increase broad insight for students, they must read a lot. However, not all students like to read books and reading material, especially those who speak English. The low interest in reading English reading material influences the number of vocabulary students have. The amount of vocabulary a person has will increase as the person often reads English-language reading so reading is a habit. Of course, vocabulary can develop through various ways but the best is through reading habits. Birch (2015), "Poor readers avoid reading, and lack of reading practice means they do not improve". By reading, the vocabulary will increase. Smith (1978) states: "Words are learned by reading, just as speech is learned through an active involvement in spoken language".

By reading other than we can enjoy the work of others, we can also learn the knowledge and experience of the scientists conveyed through the articles. The low ability of students to master English vocabulary is a very big cause for these students to understand the discourse in English that he reads. This problem also appears in AL-MAKMUR Vocational School students.

The question is how to increase interest and students' reading comprehension abilities in English. The author focuses on the ability of reading comprehension in low English because of the lack of vocabulary owned by students of AL-MAKMUR Vocational School. By looking at this, the author intends to overcome this difficulty. This encourages the author to present one of the English vocabulary teaching techniques to improve reading comprehension skills of AL-MAKMUR Vocational students using the Buddy Vocabulary Cards technique.

Reading is a process of thinking by connecting information obtained from previous reading experiences with new information obtained while reading a discourse. This was revealed by Stauffer (1969, 1975): “...reading is a thinking process that involves the reader in using his or her own experiences to reconstruct the author's ideas".

By using the information obtained from the previous reading process, the reader tries to understand the meaning of the information written by the author. If the discourse that he reads is in accordance with the background of his knowledge, he will more easily understand the discourse he reads. Therefore, in choosing a discourse the instructor should pay attention to the knowledge background possessed by his students so that they can understand the discourse given by the instructor.

When reading a discourse, understanding the discourse that is read is very necessary. The ability to 
understand a discourse is the ability to translate symbols printed in the discourse into meaningful ideas. Musodah (2014) in his writing research stated, "Reading is an activity to translate the symbols and meaning or its meaning through the senses of sight". What is meant by symbols in the sentence above is a collection of strung words into sentences that contain meaning that is a message from the author.

Vocabulary mastery in reading comprehension has a very close relationship and has a very important role. Tierney \& Readence (2005) state: "Without a doubt there exists a strong relationship between vocabulary knowledge and reading comprehension". Knowledge of meaning is a basic component of reading comprehension. The more number of vocabularies a student has and a broad background, the higher the level of reading comprehension of the student. Therefore, an integrated exploitation of activities is needed between reading comprehension and vocabulary development to improve students' reading skills. William (1990): The link between reading comprehension and vocabulary is axiomatic since knowledge of word meaning is a basic component of reading ability. An integration program of reading comprehension and vocabulary development has to be fully exploited.

Buddy Vocabulary Cards technique is an effective vocabulary teaching technique, because students will help each other in mastering the difficult vocabulary that has just been acquired. Students interact with each other because they do not learn the vocabulary themselves but work together to master difficult vocabulary and to increase the amount of vocabulary they have. Piercey (1982) expressed:
"Students can be quite effective in teaching one another with Buddy Vocabulary Cards. You will note that the technique is a variation of a card system that has been used in the classroom for a long time. The Buddy Vocabulary concept was borrowed from the practice pairing swimmers in recreational swimming, each being responsible for the other's safety, as well as imitiative instruction. Instead of each student working on vocabulary cards alone, as in the custom, each works with a buddy. Buddies help each other master trouble some words".

The activity of writing Buddy Vocabulary Cards is the activity of making cards 2 (two) sides measuring $3 \times 5$ inches which contain writing sentences in which there are difficult words and how to pronounce the difficult word. This activity is on the front side. While on the backside students write back what has been written on the front side plus the meaning of the difficult word. The function of the backside of Buddy Vocabulary Cards is for students who help students who have difficulty mastering difficult words.

The meaning of the word on the second side is because students who have difficulty have to guess the difficult word based on the context first. After that, he tried but could not also, then his friend can tell the meaning of the word. What must be remembered in this activity is the meaning of the word must be based on context. As revealed by Piercey (1982): "Note again the emphasis on the words in context, not in isolation".

Piercey strongly advocates the use of vocabulary teaching techniques through Buddy Vocabulary Cards because this technique can increase the number of vocabulary of someone who does this activity without exception, so 
that the stigma of "stupid students" can be eliminated as well as mutual cooperation between students and others, so that the interacting process can occur well. If this activity is carried out continuously then, the number of vocabularies a person has will increase so that the level of reading comprehension will increase.

In order to the vocabulary that has been learned does not just disappear, then each teacher meeting carries out activities that can make students recall the vocabulary that they have made, practiced and also memorized so that the vocabulary does not just disappear. In addition, the instructor carries out this activity continuously.

In Buddy Vocabulary Cards several things are discussed, namely spelling, pronunciation. Spelling is forming words with the correct letters in the correct order. Spelling error or misspelling is the mis-selection of a grapheme to represent a syllable or morpheme in forming part of a word (James, 1998). When we talk about spelling, we associate with phonemes too. Gimson \& Ramsaran (1970) acknowledged that phoneme is the smallest contrastive linguistics unit that brings about change in meaning of words in a language. That phoneme is a sound unit that exists in language and is not a letter. Examples of gun words ( $\mathrm{g} n$ ) consist of three phonemes, great (gr t) consisting of four phonemes, bloody (bl di) consisting of five phonemes and so on.

Moreover, Pennington (1989) states "The pronunciation is defined with reference to the patterns in individual words of good stress and pitch". Pronunciation is defined by reference to an individual word pattern consisting of correct word pressure and pitch. In the Buddy Vocabulary Cards technique, the meaning of words obtained by students is obtained from teachers or other smart students. The author wants to vary the way the word meaning is obtained by students by guessing the meaning of difficult words based on context (contextual guessing). This method is good for students because students play an active role in gaining meaning from a difficult word found by students in the reading process.

Besides looking for difficult words in the dictionary, learning words through their context can increase the number of vocabulary words. Teaching vocabulary by guessing difficult words based on the context is very important because when students find difficult words at the time of reading, he will remember the word as part of a story that is attached longer than if he directly sees the meaning of the word through a dictionary. The Buddy Vocabulary Cards technique includes four basic skills, namely: 1) reading-contextual guessing and reading aloud, 2) listenhard and discuss, 3) speakpronunciation, and 4) writing-making Buddy Vocabulary Cards.

\section{METHOD}

This research was conducted at AL-MAKMUR Vocational School, an Islamic education institution located on Jl. Kahfi I Ciganjur - Jagakarsa South Jakarta. Previous research has been carried out to improve students' reading comprehension ability by using the Buddy Vocabulary Cards method as many as three meetings in class 1 students taken 44 randomly.

Data collection methods used in obtaining data using survey methods, with techniques classified in 2 (two) parts, namely:

\section{Library Research}

That is a study and data collection by studying and reading books, learning outcomes records during 
the education period and other reading sources that have to do with the problems discussed.

\section{Field Research}

Namely, the research carried out directly on the object, the authors obtain data through question and answer and provide some questions to students.

The object of the study was all first grade students with a population of 239 students. Based on the total population, the researcher took a sample of 44 random students in this study. Analysis of the data used is by analyzing the questions and some of the skills that the author gives. Then this data will be presented in the form of a list of tables that will look for the average value to see the effectiveness of the use of Buddy Vocabulary Cards techniques in an effort to improve reading comprehension skills in students.

\section{RESULTS AND DISCUSSION}

Before the teaching and learning activities begin, the teacher first determines the objectives to be achieved and prepares teaching materials to be given to students. Six sub-reading skills will be taught, namely:

1. Scanning: search for information or facts in a discourse quickly.

2. Skimming: looking for the mind of a paragraph or a discourse.

3. Contextual Guessing: guess the meaning of difficult words based on the context.

4. Discourse Markers and Patterns: recognize conjunctions that connect one sentence to another.

5. Reference: replace a word for a reference word.

6. Inference: draw conclusions for a sentence or more.

From the results of the research conducted, there is an overall value of students in teaching and learning activities. In this case, the author only presents the average value of students, the highest value achieved by students and the lowest value achieved by students.

$$
\begin{gathered}
\text { Average score }=\frac{\text { Student Value Amount }}{\text { Student Amount }} \\
\bar{x}=\frac{1}{n} \sum_{i=1}^{n} x i \quad=\frac{1}{44}(300)=6,8
\end{gathered}
$$

Highest score $\quad=8$

Lowest score $\quad=5$

To see the size of the effectiveness of the Buddy Vocabulary Cards technique in its application in teaching and learning activities the writer will first make a category of effectiveness level, which is presented based on the list of values above. Effectiveness category:

1. Average $8 \sim 10=$ Very Good

2. Average $6,8 \sim 7,9=$ Good

3. Average $5,6 \sim 6,7=$ Enough

4. Average 4,5 5,5 = Less

5. Average $<4,4=$ Very Less

Looking at the students presented average above, that is 6.8 , then if it is included in the category of effectiveness, the number falls into GOOD category, this means teaching English vocabulary through the Buddy Vocabulary Cards technique in an effort to increase reading comprehension ability of AL-MAKMUR Vocational School students have reached the level of effectiveness to be presented to students.

The discussion of the results of teaching English reading discourse skills is described as follows:

\section{Student Ability}

a. Contextual Guessing: students' ability to guess words based on their context is very lacking, so they need to get training.

b. Pronunciation: students' ability to recite words in English is very 
lacking, so they still need to get training again.

c. Remembering new words: the ability of students to remember new words using the Buddy Vocabulary Cards method is pretty good, so if they want to practice hard again they will get new words they get.

\section{Planning and Preparation}

Planning / preparation and preparation in teaching in the class are divided into several stages, namely: lead-in, teacher directs, task comprehension, teacher directs feedback, text-related tasks, evaluation, and closure.

\section{Use of aids}

Exercise paper and cartons used to make vocabulary cards. In this training paper, there are passages, sub exercises in reading comprehension skills, and evaluations in the form of questions and filling in the gap with the appropriate words.

\section{Correcting Technique}

Do by the teacher and between students when and after they do the exercises.

\section{Learning Speed}

The teaching and learning process initially runs slowly, but then students can follow it easily, because they are already getting used to repetitive training to get maximum results.

6. Variety

This trial was conducted with three learning units. At the first meeting of teaching-learning activities and the results achieved were not encouraging, but at the next meeting they were able to follow them well, so that the results achieved were quite encouraging.

\section{Class Situation}

The class situation is very active because they must interact to do the exercises given each other. Student relations with teachers are very good because the instructor provides excellent input to the students. They did not hesitate and were awkward to ask about what they wanted to know and how to pronounce it.

\section{Response and Motivation}

Give praise and judgment if students can do the exercises without mistakes, so they are motivated to do better. For students who make mistakes also be encouraged not to be deterred to try to answer questions. They describe a very good response in the teachinglearning process.

\section{CONCLUSION}

Based on the description of the research data and after the analysis, it can be concluded that the teaching model through the Buddy Vocabulary Cards technique can be used to improve reading comprehension skills of ALMAKMUR Vocational School students, but has not reached a maximum value, but the average value of students has reached the category GOOD, with an average value of 6.8 .

In the teaching and learning process, the Buddy Vocabulary Cards technique reaches the level of effectiveness to be presented to students because they become active and learning becomes very pleasant, so students are eager to participate in teaching and learning activities.

The Buddy Vocabulary Cards method can be used to train students to memorize English words well. Buddy Vocabulary Cards technique is one technique that can be used to improve reading, listening, speaking and writing skills. The use of the Buddy Vocabulary Cards technique is more appropriate for improving students' abilities in English vocabulary, especially for students at the beginning of introducing English teaching. 


\section{REFERENCES}

Birch, M. B. (2015). English L2 Reading. English L2 Reading (Third Edit). Routledge. https://doi.org/10.4324/978141061 4933

Gimson, A., \& Ramsaran, S. (1970). An Introduction to the Pronunciation of English (Vol. 4). London: Edward Arnold.

James, C. (1998). Errors in Language Learning and Use: Exploring Error Analysis. London: Longman.

Musodah, A. (2014). Peningkatan Kemampuan Membaca Permulaan Melalui Media Kartu Kata Bergambar Pada Anak Kelompok B2 Ra Ma'arif Nu Karang Tengah Kertanegara Purbalingga. Skripsi.

Pennington, M. C. (1989). Teaching Proununciation from the Top Down. RELC Journal, 20(1), 2038. https://doi.org/10.1177/003368828 902000103

Piercey, D. (1982). Reading activities in content areas: an ideabook for middle and secondary schools. Allyn and Bacon. Retrieved from https://books.google.co.id/books?i d=-T8mAQAAIAAJ

Smith, F. (1978). Reading. London, New York: Cambridge University Press.

Stauffer, R. G. (1969). Directing Reading Maturity as a Cognitive Process. Harper \& Row. . (1975). Directing the reading-thinking process. Harpercollins.

Tierney, R. J., \& Readence, J. E. (2005). Reading Strategies and Practices: A Compendium. Boston: Pearson.

William, D. (1990). Reading as a thematic link in integrative unit. English Teaching Forum, 19-20. 